\title{
On the causal association between exposure to leather dust and nasal cancer: further evidence from a case-control study
}

\author{
E MERLER, ${ }^{1}$ A BALDASSERONI, ${ }^{2}$ R LARIA,${ }^{3}$ P FARAVELLI, ${ }^{4}$ R AGOSTINI, ${ }^{4}$ \\ R PISA, ${ }^{1}$ AND F BERRINO
}

From the Istituto di Anatomia e Istologia Patologica, ${ }^{1}$ Università di Verona, Servizio di Epidemiologia, ${ }^{2}$ Istituto Nazionale per lo Studio e la Cura dei Tumori, Milan, Reparto Otorinolaringoiatrico, ${ }^{3}$ Ospedale di Vigevano, Vigevano, and Unità Sanitaria Locale No $78,{ }^{4}$ Lombardy, Italy

ABSTRACT A case-control study was performed on the incident cases of nasal cavity tumours which occurred between 1968 and 1982 among the residents of Vigevano (Lombardy region, northern Italy). This area is characterised by a high prevalence of shoemakers (especially in leather); the activity has predominated in Vigevano since the beginning of this century. Twenty one cases were identified (16 men and five women); 20 were histologically confirmed as nasal epithelial tumours; 17 had already died at the time of interview and the occupational history was obtained from the next of kin. Two controls per case were selected from the general population and matched by vital status, age, sex, and residence. The overall odds ratio for the subjects exposed to leather dust was $47 \cdot 1$ for men and 3.5 for women. The odds ratio was higher for adenocarcinoma and among the workers exposed to the worst working conditions. A significant trend for the level of exposure to leather dust was found. Nevertheless, even the jobs characterised by a relatively low exposure were found to have a significantly higher risk $(O R=7 \cdot 5)$. Smoking habits and exposure to solvents are unlikely to confound the relation between exposure to leather and nasal tumours.

Two studies conducted in Europe have provided evidence for an association between leather shoe and boot manufacture and epithelial nasal and paranasal tumours (especially adenocarcinomas.) ${ }^{12}$ The excess risk occurs mainly among workers exposed to dusty jobs such as sole and heel trimming, bottom scouring, and finishing. Prolonged exposure and long latent periods have generally been observed. Similar observations have also been made for exposure to wood dust. $^{3}$ To provide further evidence, a case-control study of nasal and paranasal tumours was conducted in the city of Vigevano, $30 \mathrm{~km}$ (18 miles) from Milan in northern Italy.

The Italian shoe and boot manufacturing industry began to develop in Vigevano in 1876 and in 1911 leather shoe production was the highest in Italy. Military demand during the Lybic war and the first world war caused a great increase in production. In 1927 an important rubber shoe production began and between 1945 and 1965 further expansion, mainly directed towards foreign markets, took place. In this

Accepted 27 June 1985 period shoe manufacture was the town's main economical activity and table 1 shows the number of employees engaged in shoe manufacture in the census years from 1911 to 1981 ; the total population of Vigevano was 27746 in 1911 and 65228 in 1981.4 In Vigevano leather was used only to make shoes, no other leather goods were manufactured. Leather was tanned elsewhere but since the 1920s most of the machinery for shoe manufacture has been produced locally. Production was located in small factories and at home and many cases of benzene leukaemia and solvent neuropathy have been reported among the shoe makers. ${ }^{56}$

\section{Material and methods}

The cases were all the incident malignant tumours of the nasal cavity and paranasal sinuses occurring among the residents of Vigevano between 1968 and 1982. The sources of cases were inpatient and outpatient records from the otolaryngology departments of the local hospital and two nearby hospitals at Abbiategrasso and Pavia (15 cases), the hospital can- 
Table 1 Employees in the shoe leather industry in the city of Vigevano at various censuses

\begin{tabular}{|c|c|c|c|c|c|c|}
\hline Year & Men & Women & Total & No of factories & $M / F$ & No of employees per factory \\
\hline $\begin{array}{l}1911 \\
1921 \\
1931 \\
1951 \\
1961 \\
1971 \\
1981\end{array}$ & $\begin{array}{l}1205 \\
3026 \\
3989 \\
4687 \\
6992 \\
3434 \\
-\end{array}$ & $\begin{array}{l}1271 \\
2752 \\
3920 \\
3667 \\
7043 \\
5215 \\
-\end{array}$ & $\begin{array}{r}2476 \\
5814 \\
7909 \\
8354 \\
14035 \\
8649 \\
7780\end{array}$ & $\begin{array}{l}191 \\
448 \\
540 \\
872 \\
834 \\
591 \\
666\end{array}$ & $\begin{array}{l}0: 95 \\
1: 09 \\
1: 01 \\
1: 28 \\
0: 99 \\
0: 66 \\
-\end{array}$ & $\begin{array}{r}12.9 \\
12.9 \\
14.6 \\
9.6 \\
16.8 \\
14.6 \\
11.7\end{array}$ \\
\hline
\end{tabular}

cer registry of the National Cancer Institute of Milan ( 2 cases), and the mortality records of the city ( 2 cases). Two additional cases were identified through the practising otolaryngologists of Vigevano.

To evaluate the completeness of patient retrieval, we examined the list of all residents of Vigevano discharged from the hospitals of the Lombardy region (in which Vigevano lies) through the hospital discharge reporting system, active since 1976, but no additional cases were traced. A total of 21 incident cases ( 16 men, 5 women) was identified, 20 of which were histologically confirmed; for 14 cases it was possible to trace the original slides or unstained sections for histological review. For one case histological confirmation was missing but we could accept the diagnosis through other clinical sources.

Four cases were still alive and were interviewed and 17 were dead and were replaced by a close relative. Two controls per case were matched by age $( \pm 5$ years) sex, vital status, and, if dead, year of death. Live controls were randomly selected from the Vigevano electoral roll which includes all residents aged over 18. Dead controls were extracted from mortality records, choosing the two nearest subjects with the appropriate matching characteristics and dead from non-cancer causes. All live controls were traced and interviewed. For seven of the 34 dead controls first selected, the relatives were untraceable. These seven controls were replaced by the next ones selected by the methods described above. Relatives of four of these replacements were located and interviewed; the other three whose relatives could not be traced, were not replaced. Two of us (AB and EM, occupational physicians) collected information on the occupational histories, and smoking habits of all the patients after a detailed and standardised scheme of interview. In most cases the relatives of the study subjects had also worked in shoe manufacturing; they thus provide detailed information about specific tasks; most had worked with the subjects under study.

The presence and intensity of exposure to leather dust and to several other potential risk factors (solvents, rubber, wood dust, polycyclic aromatic hydrocarbons, nickel, benzene) were evaluated blind by two of use (PF and RA, occupational physicians in the local occupational health service) on the basis of the recorded interviews. The exposure categories were: "-" for no exposure, "+" for uncertain or light exposure and " ++ " for heavy exposure. The estimated level of exposure took into account the specific tasks, workplaces, duration, technology, and hygienic evaluation.

Statistical analyses of the data were based on the Mantel-Haenszel procedures for the calculation of $p \dot{\sim}$ values and for estimation of overall odds ratio (OR). ${ }^{7} \underline{6}$ The $95 \%$ confidence limits of the OR (CL 95\%) was 을 computed according to Miettinen. ${ }^{8}$ The computation $\rightarrow$ of the chi-square for trends over the categories of $\pi$ exposure was based on the Mantel extention of the $\frac{\mathbb{O}}{O}$ Mantel-Haenszel test. ${ }^{9}$ Analyses were carried out using the programs written by Rothman and Boice. ${ }^{10}$ Since the analysis of matched and unmatched data $\vec{\oplus}$ gave similar results in terms of statistical significance and magnitude of $\mathrm{OR}$, the outcomes presented hes are based on unmatched sets only.

\section{Histological review}

A histopathological review of the available material was performed by RP for 14 cases. The material was mainly represented by haematoxilin-eosin stained sections. Unstained sections were requested in order to show mucin secretion by means of a PAS-alcian blue stain in poorly differentiated tumours and to identify otherwise questionable cases of adenocarcinomas. As shown in table 214 cases $(66.7 \%)$ were classified into well established histological categories. Seven tumours originally classified as adenocarcinomas $\delta$ were confirmed; by contrast, three of the seven cases previously classified as squamous or undifferentiated $\mathrm{o}$ carcinomas were considered to be poorly differentiated adenocarcinomas because of a minimal o tubular differentiation supported by unequivocal mucin secretion. One case of squamous carcinoma $\sigma$ was considered to be of sebaceous origin.

\section{Results}

Table 3 shows the distribution of the cases and controls by sex and occupational exposure to leather dust as established from occupational histories. The crude $\mathrm{OR}$, comparing the exposed, with any category of 
Table 2 Concordance of the review of the 20 cases confirmed histologically

\begin{tabular}{|c|c|c|c|c|c|}
\hline \multirow{2}{*}{$\begin{array}{l}\text { Histological type in original } \\
\text { diagnosis }\end{array}$} & \multicolumn{2}{|c|}{ Established by independent review } & \multirow{2}{*}{$\begin{array}{l}\text { Other primary } \\
\text { cancer }\end{array}$} & \multirow{2}{*}{$\begin{array}{l}\text { Not available for } \\
\text { review }\end{array}$} & \multirow[t]{2}{*}{ Total } \\
\hline & Adenocarcinomas & Epidermoid cancer & & & \\
\hline $\begin{array}{l}\text { Adenocarcinomas } \\
\text { Epidermoid carcinomas } \\
\text { Other primary cancer } \\
\text { Total }\end{array}$ & $\begin{array}{r}7 \\
0 \\
3 \\
10\end{array}$ & $\begin{array}{l}0 \\
3 \\
0 \\
3\end{array}$ & $\begin{array}{l}0 \\
1 \\
0 \\
1\end{array}$ & $\begin{array}{l}4 \\
1 \\
1 \\
6\end{array}$ & $\begin{array}{r}11 \\
5 \\
4 \\
20\end{array}$ \\
\hline
\end{tabular}

exposure, to the never exposed is $\mathbf{1 7 \cdot 4}$. After controlling for sex the OR becomes $15 \cdot 7$ (CL 95\% 4.6-54.0). The OR was much higher for men (47.1 with CL $95 \%$ 8.7-255.1) than for women (3.5 with CL 95\% $0 \cdot 2-59 \cdot 0)$. Most of the difference, however, may be attributed to the higher exposure of the male workers; only men were classified into the highest exposure category. The OR for the highest category of exposure was 121.0 (CL 95\% 17.3-844.3) and for the intermediate adjusted for sex, $7 \cdot 5$ (CL 95\% 1.8-31-7). This corresponded to a highly significant dose-response trend $(p<0.001)$.

Table 4 shows the same distribution for adenocarcinomas only. The overall sex adjusted OR, comparing exposed and unexposed subjects, was $41 \cdot 4$ (CL 95\% 7.6-226.8).

For the highest exposure the OR was 88.0 (CL 95\% 12.1-642.0) and for the intermediate exposure, $20 \cdot 4$ (CL 95\% 2.7-152.0). A much lower effect of exposure was observed for tumours other than adenocarcinomas (table 5). In this case the overall OR was 6.9 (CL 95\% 1.4-34.4). The table includes one case not histologically verified and two cases for which the slides were not available for review. After exclusion of these cases (two exposed men and a woman not exposed) the difference is no longer statistically significant (OR $=0.6$ with CL $95 \% 0.8-42.3$ ).

Table 6 shows the distribution of cases and controls by exposure to solvents and to leather dust. The effect of leather is still evident having allowed for exposure to solvents $(O R=12.9$ with CL 95\% 1.6-104.4). There is no indication of any effect of the exposure to solvents. One must bear in mind, however, that the leather workers more exposed to solvents are usually less exposed to leather dust.

Table 3 Distribution of nasal epithelial tumours and sex adjusted standardised $O R$ by leather dust exposure

\begin{tabular}{|c|c|c|c|c|}
\hline & \multicolumn{4}{|c|}{ Leather dust exposure } \\
\hline & ++ & + & - & Total \\
\hline $\begin{array}{l}\text { Men: } \\
\text { Cases } \\
\text { Controls } \\
\text { Women: }\end{array}$ & $\begin{array}{r}11 \\
2\end{array}$ & $\begin{array}{l}4 \\
5\end{array}$ & $\begin{array}{r}1 \\
22\end{array}$ & $\begin{array}{l}16 \\
29\end{array}$ \\
\hline $\begin{array}{l}\text { Cases } \\
\text { Controls } \\
\text { OR } \\
\text { (CL 95\%) }\end{array}$ & $\begin{array}{l}\bar{z} \\
121 \cdot 0 \\
(17 \cdot 3-844 \cdot 3)\end{array}$ & $\begin{array}{l}3 \\
3 \\
7 \cdot 5 \\
(1 \cdot 8-31 \cdot 7)\end{array}$ & $\begin{array}{l}2 \\
7 \\
1\end{array}$ & $\begin{array}{r}5 \\
10\end{array}$ \\
\hline
\end{tabular}

Similar results were obtained when exposure to benzene was examined. No association was observed with rubber shoe production. No case and only two controls were exposed to wood dust. One case and one control were possibly exposed to nickel compounds. One case and one control were judged to have been heavily exposed to polycyclic aromatic hydrocarbons.

All the cases exposed to leather dust worked in the leather industry for 12 years or more. Two controls, by contrast, worked for only five and three years (table 7).

Among men smoking habits were similar in cases $(81.8 \%$ smokers) and controls (82.6\%); only one woman, a control, was a smoker.

\section{Discussion}

The study shows a high risk of nasal cancer associated with exposure to leather dust, thus confirming previous observations. ${ }^{12}$ A clear dose-effect relation, which had only been suggested by the previous studies, was also observed. The effect was much stronger for adenocarcinomas; the results, however, indicate that the risk is increased also for other epithelial cancers. The association holds for both men and women; none of the women, however, was classifiable within a high $(++)$ level of exposure, so that the OR for women is not significantly different from one. In our opinion it is unlikely that this result can be explained by selection bias. An effort was made to contact all the posssible cases of nasal tumours developing among the residents within a defined period and the controls were drawn from a comparable source-the general population of the same area.

Table 4 Distribution of nasal adenocarcinomas and sex adjusted standardised $O R$ by leather dust exposure

\begin{tabular}{|c|c|c|c|c|}
\hline & \multicolumn{4}{|c|}{ Leather dust exposure } \\
\hline & ++ & + & - & Total \\
\hline $\begin{array}{l}\text { Men: } \\
\text { Cases } \\
\text { Controls } \\
\text { Women: }\end{array}$ & $\begin{array}{l}8 \\
2\end{array}$ & $\begin{array}{l}3 \\
5\end{array}$ & $\begin{array}{r}1 \\
22\end{array}$ & $\begin{array}{l}12 \\
29\end{array}$ \\
\hline $\begin{array}{l}\text { Cases } \\
\text { Controls } \\
\text { OR } \\
\text { (CL 95\%) }\end{array}$ & $\begin{array}{l}\overline{-} \\
88 \cdot 0 \\
(12 \cdot 1-642 \cdot 0)\end{array}$ & $\begin{array}{l}2 \\
3 \\
20 \cdot 4 \\
(2 \cdot 7-152 \cdot 0)\end{array}$ & $\overline{7}$ & $\begin{array}{r}2 \\
10\end{array}$ \\
\hline
\end{tabular}


Table 5 Distribution of nasal tumours other than adenocarcinomas and sex adjusted standardised $O R$ by leather dust exposure

\begin{tabular}{lllll}
\hline \multicolumn{5}{c}{ Leather dust exposure } \\
\cline { 2 - 5 } & ++ & + & - & Total \\
\hline $\begin{array}{l}\text { Men: } \\
\text { Cases }\end{array}$ & 3 & 1 & -1 & 4 \\
$\begin{array}{c}\text { Controls } \\
\text { Women: }\end{array}$ & 2 & 5 & 22 & 29 \\
$\begin{array}{l}\text { Cases } \\
\text { Controls }\end{array}$ & - & 1 & 2 & 3 \\
$\begin{array}{l}\text { OR } \\
\text { (CL 95\%) }\end{array}$ & $(1.4-34.4)$ & 3 & 7 & 10 \\
\hline
\end{tabular}

Table 6 Distribution of nasal epithelial tumours exposure to $\overline{\bar{\alpha}}$ solvents and leather dust

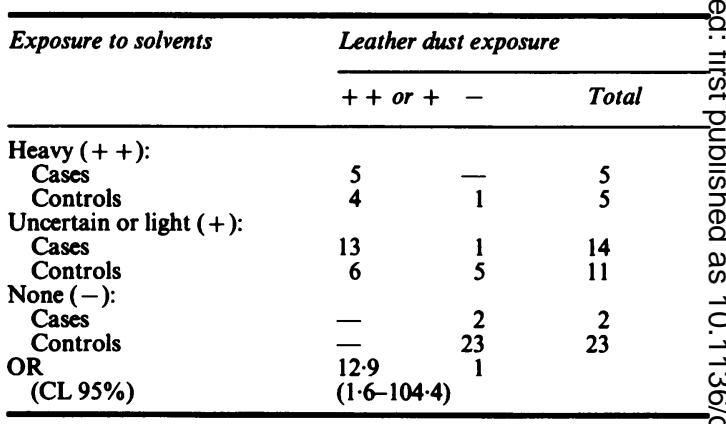

Table 7 Summary of occupational data obtained in 28 subjects (18 cases and 10 controls) associated at some time with the leather trade

\begin{tabular}{|c|c|c|c|c|c|c|c|c|c|c|}
\hline $\begin{array}{l}\text { Case } \\
\text { No }\end{array}$ & $\operatorname{Sex}$ & $\begin{array}{l}\text { Year of } \\
\text { birth }\end{array}$ & $\begin{array}{l}\text { Year of entry } \\
\text { to industry }\end{array}$ & Nature of industry & $\begin{array}{l}\text { Occupation in boot and } \\
\text { shoe manufacture }\end{array}$ & $\begin{array}{l}\text { Year left } \\
\text { industry }\end{array}$ & $\begin{array}{l}\text { Year of } \\
\text { diagnosis }\end{array}$ & Histology & $\begin{array}{l}\text { Exposure } \\
\text { to leather } \\
\text { dust }\end{array}$ & $\begin{array}{l}\text { Explosu } \\
\text { solisints } \\
\text { d } \\
\end{array}$ \\
\hline & & \multicolumn{9}{|c|}{ Cases } \\
\hline $\begin{array}{l}01 \\
02 \\
03\end{array}$ & $\begin{array}{l}\mathbf{M} \\
\mathbf{M} \\
\mathbf{M}\end{array}$ & $\begin{array}{l}1907 \\
1924 \\
1908\end{array}$ & $\begin{array}{l}1919 \\
1945 \\
1920\end{array}$ & $\begin{array}{l}\text { Small factories } \\
\text { Factories } \\
\text { Factories and } \\
\quad \text { workshop }\end{array}$ & $\begin{array}{l}\text { All skills and foreman } \\
\text { Warehouseman } \\
\text { Trimmer and scourer }\end{array}$ & $\begin{array}{l}1967 \\
1978 \\
1968\end{array}$ & $\begin{array}{l}1968 \\
1978 \\
1981\end{array}$ & $\begin{array}{l}\text { Adenocarc } \\
\text { Adenocarc } \\
\text { Adenocarc }\end{array}$ & $\begin{array}{l}++ \\
+ \\
++\end{array}$ & $\begin{array}{l}+\bar{c} \\
\text { 市 } \\
\text { 要 }\end{array}$ \\
\hline $\begin{array}{l}04 \\
05 \\
06 \\
07 \\
08\end{array}$ & $\begin{array}{l}\mathbf{M} \\
\mathrm{F} \\
\mathbf{M} \\
\mathbf{M} \\
\mathrm{F}\end{array}$ & $\begin{array}{l}1913 \\
1901 \\
1908 \\
1903 \\
1905\end{array}$ & $\begin{array}{l}1925 \\
1920 \\
1923 \\
1926 \\
1920\end{array}$ & $\begin{array}{l}\text { Workshop } \\
\text { Workshops } \\
\text { Small factories } \\
\text { House } \\
\text { House and } \\
\text { small factory }\end{array}$ & $\begin{array}{l}\text { Trimmer and scourer } \\
\text { Clicker } \\
\text { Laster } \\
\text { Craftsman } \\
\text { Laster }\end{array}$ & $\begin{array}{l}1973 \\
1951 \\
1933 \\
1968 \\
1980\end{array}$ & $\begin{array}{l}1977 \\
1971 \\
1972 \\
1971 \\
1980\end{array}$ & $\begin{array}{l}\text { Transitional } \\
\text { Squamous ca } \\
\text { Adenooarc } \\
\text { Adenocarc } \\
\text { Adenocarc }\end{array}$ & $\begin{array}{l}++ \\
+ \\
+ \\
++ \\
+\end{array}$ & 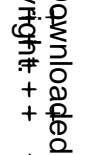 \\
\hline $\begin{array}{l}09 \\
10 \\
11 \\
12 \\
13\end{array}$ & $\begin{array}{l}\mathbf{M} \\
\mathbf{M} \\
\mathbf{M} \\
\mathbf{M} \\
\mathbf{F}\end{array}$ & $\begin{array}{l}1920 \\
1921 \\
1921 \\
1908 \\
1897\end{array}$ & $\begin{array}{l}1932 \\
1934 \\
1939 \\
1920 \\
1909\end{array}$ & $\begin{array}{l}\text { Factories } \\
\text { Small factories } \\
\text { Small factories } \\
\text { Factories } \\
\text { Factories and } \\
\quad \text { house }\end{array}$ & $\begin{array}{l}\text { Trimmer and scourer } \\
\text { Trimmer and scourer } \\
\text { Trimmer and scourer } \\
\text { Trimmer and scourer } \\
\text { Clicker and laster }\end{array}$ & $\begin{array}{l}1974 \\
1969 \\
1969 \\
1968 \\
1963\end{array}$ & $\begin{array}{l}1974 \\
1969 \\
1972 \\
1969 \\
1979\end{array}$ & $\begin{array}{l}\text { Adenocarc } \\
\text { Adenocarc } \\
\text { Squamous ca } \\
\text { Squamous ca } \\
\text { Adenocarc }\end{array}$ & $\begin{array}{l}++ \\
++ \\
++ \\
++ \\
+\end{array}$ & $\begin{array}{l}+\frac{0}{\overrightarrow{5}} \\
+\frac{0}{3} \\
+\frac{5}{0} \\
+\frac{7}{0}\end{array}$ \\
\hline 14 & $\mathbf{M}$ & 1927 & 1943 & $\begin{array}{l}\text { Workshop and } \\
\text { house }\end{array}$ & Trimmer and scourer & 1971 & 1981 & Adenocarc & ++ & \\
\hline 15 & $\mathbf{M}$ & 1912 & 1928 & $\begin{array}{l}\text { Factories and } \\
\text { house }\end{array}$ & Finisher & 1972 & 1975 & Adenocarc & ++ & $+\frac{0}{3}$ \\
\hline \multirow[t]{2}{*}{$\begin{array}{l}16 \\
17 \\
18\end{array}$} & $\begin{array}{l}\mathbf{M} \\
\mathbf{M} \\
\mathbf{M}\end{array}$ & $\begin{array}{l}1912 \\
1899 \\
1903\end{array}$ & $\begin{array}{l}1949 \\
1914 \\
1915\end{array}$ & $\begin{array}{l}\text { Small tanneries } \\
\text { Workshop } \\
\text { Small factories } \\
\text { and workshop }\end{array}$ & $\begin{array}{l}\text { Tanner } \\
\text { Craftsman } \\
\text { Owner and all skills }\end{array}$ & $\begin{array}{l}1967 \\
1960 \\
1971\end{array}$ & $\begin{array}{l}1976 \\
1971 \\
1972\end{array}$ & $\begin{array}{l}\text { Squamous ca } \\
\text { Adenocarc } \\
\text { Adenocarc }\end{array}$ & $\begin{array}{l}+ \\
+ \\
+\end{array}$ & 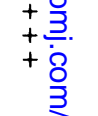 \\
\hline & & \multicolumn{9}{|c|}{ Controls } \\
\hline $\begin{array}{l}01 \\
02\end{array}$ & $\begin{array}{l}\mathbf{M} \\
\mathbf{M}\end{array}$ & $\begin{array}{l}1929 \\
1916\end{array}$ & $\begin{array}{l}1960 \\
1927\end{array}$ & $\begin{array}{l}\text { Factory } \\
\text { Small factories }\end{array}$ & $\begin{array}{l}\text { Press cutter } \\
\text { Craftsman }\end{array}$ & $\begin{array}{l}1982 \\
1973\end{array}$ & 二 & $\bar{\square}$ & $\stackrel{+}{+}$ & $\begin{array}{l}D \\
+D\end{array}$ \\
\hline 03 & $\mathbf{M}$ & 1911 & 1930 & $\begin{array}{l}\text { Factory, tannery, } \\
\text { house }\end{array}$ & $\begin{array}{l}\text { Moulder, tanner, and } \\
\text { all skills }\end{array}$ & 1968 & - & & ++ & $+\frac{1}{0}$ \\
\hline 04 & $\mathbf{F}$ & 1921 & 1938 & $\begin{array}{l}\text { Factories and } \\
\text { house }\end{array}$ & $\begin{array}{l}\text { Clicker, edge binder, } \\
\text { and fitter }\end{array}$ & 1982 & - & - & + & $+\bar{N}$ \\
\hline 05 & $\mathbf{F}$ & 1919 & 1938 & $\begin{array}{l}\text { Factories and } \\
\text { workshop }\end{array}$ & Clicker & 1956 & - & - & + & \\
\hline 06 & $\mathbf{M}$ & 1916 & 1943 & Small factories & $\begin{array}{l}\text { Craftsman, foreman, } \\
\text { machine cutter }\end{array}$ & 1981 & - & & + & $+N$ \\
\hline 07 & $\mathbf{M}$ & 1901 & 1915 & Workshop & $\begin{array}{l}\text { Craftsman, machine } \\
\text { cutter }\end{array}$ & 1960 & - & & + & $+\underset{0}{\sigma}$ \\
\hline 08 & $\mathbf{M}$ & 1905 & 1915 & Small factories & $\begin{array}{l}\text { Craftsman, laster, hand } \\
\text { cutter }\end{array}$ & 1967 & - & & + & $+\frac{\mathbb{2}}{\frac{1}{2}}$ \\
\hline 09 & $\mathbf{M}$ & 1922 & 1945 & - & $\begin{array}{l}\text { Finisher, trimmer, and } \\
\text { scourer }\end{array}$ & 1948 & - & & ++ & $+\stackrel{0}{\stackrel{9}{7}}$ \\
\hline 10 & $\mathbf{F}$ & 1895 & 1955 & House & Splitter and skiver & 1960 & - & $\longrightarrow$ & + & $+\frac{0}{0}$ \\
\hline
\end{tabular}


Recall bias also seems improbable since both cases and controls were matched by vital status. Although the interviewers were aware of the diagnosis, the interviewing scheme was detailed and standardised. Furthermore, it seems unlikely that any relevant exposure could have been missed since the leather manufacturing industry is the main economical activity of the area. There was no indication of a substantial confounding effect of exposure to solvents or of tobacco smoking.

It has been suggested recently that exposure to formaldehyde ${ }^{11}$ and chlorophenol ${ }^{12}$ may be associated with nasal cancer. There is no indication, however, that formaldehyde is present in leather shoe and boot manufacturing. Chlorophenols, on the other hand, are often used in tanning as preservative agents, but this has become common in Italy only since the 1960s. The highest proportion of cases occurred among workers exposed most heavily and for the longest time to leather dust in poor working conditions, after the introduction of machine and industrialisation into shoe making. Historically, this process was characterised by the spread of production sites, often poorly ventilated and located in small rooms, and by the extension of the daily working hours. The machines used were equipped with a suction system from the beginning of the industralisation process; the suction system was, at least in 1920, applied directly to the trimming and scouring machines; the leather dust was then collected in bags and periodically removed. Despite the suction system, according to witnesses and documents, dust levels were high. Nevertheless, a high risk was not exclusively associated with heavy exposure.

Several epithelial tumours, particularly adenocarcinomas, occurred among those with trivial exposure to leather dust (table 7): a warehouseman, who worked in several factories; two craftsmen, who made shoes by hand: a man employed for 19 years in a small leather tannery who worked also as a shaver; and three women performing only clicking operations or preparing and assembling the upper components of the shoes.

Unfortunately, we cannot determine when the rates of nasal cancer began to increase in this area, since the data are defective before 1968; hence the period chosen for our study. In the study we consider only cases who lived in Vigevano, whereas many people came to work in the shoe factories from other nearby municipalities.

Present epidemiological research in the shoe manufacturing industry does not show which specific causal agents are concerned; it has been suggested that the chemical substances introduced through the vegetable tanning process (used specifically for soles and heels, the only trimmed parts) could play a part. ${ }^{13}$ In a recent study on a cohort of tanners one death from nasal cancer was observed compared with 0.21 expected among the men employed in making leather tanned by vegetable extracts. ${ }^{14}$ This suggestive hypothesis needs to be confirmed experimentally or by other epidemiological studies performed in tanneries or in industries manufacturing leather goods other than shoes.

We thank the directors of otolaringology and pathology departments who provided the histological material of the nasal tumours. Dr P Toniolo kindly revised the text.

The research was partially supported by grant No 84.00448.44 from Consiglio Nazionale Ricerche, Italy, as a part of the "Progetto Finalizzato Oncologia."

A preliminary report was presented at the XXI International Congress on Occupational Health, Dublin, 9-14 September 1984.

\section{References}

${ }^{1}$ Acheson ED, Cowdell RH, Jolles B. Nasal cancer in the Northamptonshire boot and shoe industry. Br Med J 1970;i:385-93.

${ }^{2}$ Cecchi F, Buiatti E, Kriebel D, Nastasi L, Santucci M. Adenocarcinoma of the nose and paranasal sinuses in shoemakers and woodworkers in the province of Florence, Italy (1963-77). Br J Ind Med 1980;37:222-5.

${ }^{3}$ International Agency for Research on Cancer monographs. Evaluation of the carcinogenic risk of chemicals to humans. Wood. leather and some associated industries. Vol 25. Lyon: IARC, 1981.

4 Istituto Centrale di Statistica. Censimenti generali della popolazione. Rome: Censimenti dell'Industria e del Commercio, 1911, 1921, 1931, 1951, 1961, 1971, 1981.

${ }^{5}$ Vigliani EC. Osservazioni cliniche su 47 casi di polineurite motorie manifestatesi in operai lavoranti con mastici e collanti. Lavoro Umano 1968;20:448-56.

${ }^{6}$ Vigliani EC. Leukemia associated with benzene exposure. Ann NY Acad Sci 1976;271:143-51.

${ }^{7}$ Mantel N, Haenszel W. Statistical aspects of the analysis of data from retrospective studies of disease. JNCI 1959;22:719-48.

${ }^{8}$ Miettinen OS. Estimability and estimation in case-referent studies. Am J Epidemiol 1976;103:226-35.

${ }^{9}$ Mantel N. Chi-square tests with one degree of freedom: extension of the Mantel-Haenszel procedure. Journal of the American Statistical Association 1963;59:690-700.

${ }^{10}$ Rothman KJ, Boice JD. Epidemiologic analysis with a programmable calculator. Washington: US Department of Health, Education and Welfare, 1973. (NIH publication No 79.)

${ }^{11}$ Olsen JH, Jensen SP, Mogens H. Occupational formaldehyde exposure and increased nasal cancer risk in man. Int $J$ Cancer 1984;34:639-44.

${ }^{12}$ Hardell L, Johansson B, Axelson O. Epidemiological study of nasal and nasophyaryngeal cancer and their relation to phenoxy acid and chlorophenol exposure. Am J Ind Med 1982;3:247-57.

${ }^{13}$ Acheson ED, Pippard EC, Winter PD. Nasal cancer in the Northamptonshire boot and shoe industry: is it declining? Br J Cancer 1982;46:940-6.

${ }^{14}$ Pippard EC, Acheson ED, Winter PD. Mortality of tanners. Br J Ind Med 1985;42:285-7. 